DOI 10.24147/2542-1514.2020.4(2).85-98

\title{
AWARD POLICY: TYPES OF AWARDS FOR THE MUNICIPAL AUTHORITIES
}

\author{
Ekaterina S. Shugrina ${ }^{1,2}$ \\ ${ }^{1}$ Russian Presidential Academy of National Economy and Public Administration (RANEPA), Moscow, Russia \\ ${ }^{2}$ Ugra State University, Khanty-Mansiysk, Russia
}

\section{Article info}

Received-

2020 March 21

Accepted -

2020 May 15

Available online -

2020 July 03

\section{Keywords}

Award policy, state awards, system of municipal awards, merit, contribution to

development, encouragement, local self-government
The subject of the research is the establishment and application of official awards at the municipal level of government, including award legislation and the practice of its application.

The purpose of the article is to confirm or disprove the hypothesis of an existence of an award policy and system of awards for the municipal level of government in Russia.

The methodological basis of the research is the general scientific dialectical method of cognition (such as methods of analysis and synthesis, abstraction and concretization, induction, deduction and analogy), as well as the method of monitoring of legal acts, historical and legal method, system analysis.

The main results of the research. A comprehensive analysis of existing regulations and description the general contours of the award policy for the municipal level of government were made. The following classification of awards applicable to municipal authorities can be distinguished. By type of award: honorary titles, medals, distinctions and incentives, as well as grants and prizes. Depending on the subject that establishes the award: state, municipal or public awards; moreover, you should distinguish between awards established by a public legal entity (award of the Russian Federation, of the constituent entity of the Russian Federation, a municipality) or a separate public authority. Depending on the subject receiving the award (the awarding subject): awards that are established both for the municipality as a whole, and for individual officials or other employees of local self-government bodies; a separate category consists of awards provided for the territorial bodies or their representatives. Currently, there is no single document outlining the system of awards of the Russian Federation.

Conclusions. Monitoring of normative legal acts of local self-government bodies has shown that it is quite rare to find documents that regulate the award policy of a municipality. There is practically no award policy for local government bodies or their officials, as well as awards for contributions to the development of local self-government. 


\section{Introduction}

Day of local self-government (April 21) was introduced by decree of the President of the Russian Federation from 10.06.2012 N 805; on this day in 1785, Catherine II accepted the Charter of cities-a Charter for the rights and benefits of cities of the Russian Empire. In 2020 - the 235th anniversary of this event.

Usually, award procedures are timed to coincide with professional holidays. In this regard, a legitimate question arises: is there a system of awards for local government bodies and their officials?

Article 9 of Federal law No. 131-FZ of 06.10.2003" On General principles of organizing local self-government in the Russian Federation " States that municipalities, in accordance with Federal legislation and heraldic rules, have the right to establish official symbols that reflect historical, cultural, national and other local traditions and features

According to the Guidelines for the development and use of official symbols of municipalities approved by the Heraldic Council under the President of the Russian Federation on June 28, 2006, official symbols include: coats of arms, flags, official and award badges, and emblems. All official symbols of the municipality form a complex of heraldic support for this municipality.

The guidelines note that award signs (distinctions) serve as a means of visual identification of persons whose services to the municipality are officially recognized and marked by the municipality. Award badges are badges (or other wearable signs, for example: brooches, rings, bracelets, etc.), wall and table medals, Souvenirs of a special kind, valuable gifts based on the coat of arms or flag of the municipality, or bearing the image of the coat of arms or flag of the municipality. Not all awards need official approval - Souvenirs, valuable gifts, etc.can be made and awarded without special approval. However, if the award is given an official status (i.e., it is made permanent and awarded for certain services, in accordance with the established procedure and (possibly) providing certain benefits), then such an award should be approved and its sign registered in the State heraldic register of the Russian Federation.

Unfortunately, most of the available scientific publications are studies of state awards [1-6]; there are works devoted to the analysis of public awards $[7,8]$. the Analysis of awards available in municipalities is contained mainly in methodological recommendations prepared by state or local government bodies. Surprisingly, representatives of various industries are engaged in award law - theorists and labor scientists who study incentive measures; administrationists and constitutionalists who analyze the activities of state authorities. Experts in the field of municipal law could not be found in this list. According to the $\mathrm{RSCl}$, the keywords "municipal awards" are used only in one publication [9].

This article does not claim to be a scientific breakthrough in the field of municipal awards theory. The main task of the author is to monitor the existing regulations and try to outline the General outlines of the award policy for the municipal level of government, to analyze the system of awards applied for services in the field of local government.

2. Awards for the municipal level of government in the system of state awards.

Awarding is a measure of encouragement and recognition of certain achievements in a particular field. The vast majority of people clearly or not explicitly want public recognition of their performance, i.e., generally accepted external forms of approval. The prospect of being marked out, singled out from the General mass exalts a person both in their own eyes and in the eyes of other people. 
Doubly uplifting and brings a sense of greatest satisfaction when the personal opinion of the encouraged and others are United in evaluating and recognizing his merits. The award forms an active life position of citizens (both the person awarded the award and other citizens), which is based on an internal awareness of the need and desire to carry out useful activities for the state and society in the future $[10,11]$.

The legal definition of the term "award" is contained in the Regulations on state awards of the Russian Federation, approved by decree of the President of the Russian Federation from 07.09.2010 N 1099 (hereinafter-the Decree of the President of the Russian Federation). This approach is also used in regulatory legal acts of state authorities of the subjects of the Russian Federation and local self-government bodies. Under the award "should be considered established by Federal laws and laws of the subjects of the Russian Federation, as well as regulatory legal acts of state bodies, the form of state encouragement of individuals and collectives for services to the state (the Russian Federation) and its subjects"[1].

In the awarding system, it is customary to allocate awards established by Federal state authorities (state awards of the Russian Federation, other Federal awards), state authorities of the subjects of the Russian Federation (state awards of the subject of the Russian Federation and awards of state authorities of the subject of the Russian Federation), local governments (awards of municipalities and awards of local governments), as well as commercial and nonprofit organizations, including public organizations [12]. Thus, it is possible to distinguish state, municipal and public awards; each type of awards has a certain specificity, which is manifested in the peculiarities of legal regulation, award production and other aspects.
The system of state awards of the Russian Federation established by presidential decree, includes the following state awards: the highest rank of the Russian Federation; order of the Russian Federation; the insignia of the Russian Federation; medal of the Russian Federation; honorary titles of the Russian Federation. Thus, the state awards of the Russian Federation include the highest and honorary titles,orders and medals, and distinctions. Although, according to scientists, state awards should also include state awards $[1,13]$.

There is no single list of Federal awards. The analysis of normative legal acts of Federal bodies of state power makes it possible to distinguish presidential, parliamentary, governmental, judicial, departmental, and other state bodies (awards of the accounts chamber of the Russian Federation, the Prosecutor General's office of the Russian Federation, the Central election Commission, etc.).

An indirect reference to the list of departmental awards is contained in the Federal law of 12.01.1995 N 5-FZ "on veterans". Thus, according to part 1.1 of article 7 1.1. the procedure for establishing departmental insignia that give the right to confer the title "Veteran of labor" by Federal Executive authorities, whose activities are managed by the Government of the Russian Federation, and awarding these distinctions is determined by the Government of the Russian Federation . Obviously, this list does not include the diploma and gratitude of the President of the Russian Federation, parliamentary awards, awards of the judicial system, and a number of other awards established by state authorities of the Russian Federation.

Unfortunately, there is currently no single document that sets out the system of awards of the Russian Federation, but similar documents exist in the Russian regions and municipalities. Scientists have long pointed to 
the lack of systematization of regulations governing award law $[1,14]$.

To understand the system of awards applicable to the municipal level of government, it is advisable to consider the possibility of classifying awards on different grounds. You can select the following:

- by type of award: honorary titles, medals, distinctions and incentives, as well as grants and prizes;

- depending on the subject establishing the award: state, municipal or public awards; moreover, it is necessary to distinguish between awards established by a public legal entity (award of the Russian Federation, a subject of the Russian Federation, a municipality) or a separate public authority;

- depending on the subject receiving the award (the subject of the award): awards that are established both for the municipality as a whole and for individual officials or other employees of local government bodies; a separate category is made up of awards provided for CBT bodies or their representatives.

Even a cursory acquaintance with the texts of documents regulating awarding issues can reveal the range of regulated social relations:

- name and status of the award (if it is a medal or prize, it can be a description of the appearance of the award)

- name of the body or organization that establishes the award;

- description of the awarded subject (circle of persons or organizations; requirements for length of service, work experience, results obtained, etc.);

- grounds for awarding, including through a description of results or merits;

- procedure for submitting documents and determining laureates and winners (procedure for initiating award proceedings and making a decision);
- grounds and procedure for revoking or revoking the award.

There may be other issues in the regulations governing award production. For example, the principles of awarding are formulated; the award procedure is as public and solemn as possible.

\section{Awards established by Federal state} authorities.

Analysis of the current legislation shows that it is possible to allocate awards established for:

- municipalities or individual localities (cities);

- local self-government bodies;

- employees of local governments or ordinary residents.

In the Soviet Union, there were the titles "Hero City" and "hero Fortress", which were awarded for the mass heroism and courage of their defenders, shown in the struggle for freedom and independence of the Motherland . Currently, there is a title "City of military glory" and "City of labor valor".

According to article 1 of the Federal law dated 09.05.2006 No. 68-FZ "About the honorary title of the Russian Federation "City of military glory" title "City of military glory" is awarded to cities of the Russian Federation in which territory or in immediate proximity from which during fierce battles defenders of the Fatherland showed courage, firmness and mass heroism, including the cities of the Russian Federation which was awarded the title "Hero City". This honorary title was awarded to 45 cities of the Russian Federation.

In accordance with article 1 of the Federal law of 01.03.2020 N 41-FZ "On the honorary title of the Russian Federation" City of labor valor "the title" City of labor valor " is assigned to the city of the Russian Federation, whose residents made a significant contribution to achieving Victory in the great Patriotic war of 
1941 - 1945, ensuring uninterrupted production of military and civil products at industrial enterprises located on the territory of the city (hereinafter - the enterprise), and showing mass labor heroism and selflessness.

Decree of the Government of the Russian Federation of 18.08.2016 N 815 "On the all-Russian competition" Best municipal practice " approved the Regulations on the allRussian competition "Best municipal practice". Participants in the competition can be urban districts (urban districts with intra-urban divisions), urban and rural settlements.

The competition is held in the following categories, reflecting the practice of organizing municipal management and solving local issues of municipal entities:

a) urban planning policy, provision of a favorable environment for the population and development of housing and communal services;

b) municipal economic policy and management of municipal finances;

C) providing effective "feedback" with residents of municipalities, developing territorial public self-government and involving citizens in the implementation (participation in the implementation) of local self-government in other forms;

d) strengthening of interethnic peace and harmony, implementation of other measures in the field of national policy at the municipal level.

The regulation envisages that the budgets of the constituent entities of the Russian Federation in the territories which are located in municipalities, the Federal budget provides subsidies for the awarding of municipal formations - winners within budget allocations.

In other words, the competition highlights the best municipal practice, for which the municipal entity is awarded; only certain municipalities (urban districts, urban and rural settlements) are applicants.

The Decree of the President of the Russian Federation does not contain any state awards or honorary titles related to local government. However, there are honorary titles, which can get specialists, whose activities are directly or indirectly related to the municipal level, people's architect of Russia, people's teacher of Russia, honored architect of Russia, honored doctor of the Russian Federation, honored teacher of Russian Federation, etc.

The resolution of the State Duma of the Federal Assembly of the Russian Federation dated 18.10.1996 N 707-II GD established by the diploma of the State Duma of the Federal Assembly of the Russian Federation, which is unable to separate the representatives of local authorities. Currently, the Resolution of the state Duma from 18.01.2017 N 724-7 GD "On the diploma of the State Duma of the Federal Assembly of the Russian Federation" which provides that the awarding of an Honorary diploma of the State Duma of citizens and organizations made for certain services and significant contribution. However, none of the nominations explicitly mention local selfgovernment (for example, there are such nominations as: for a significant contribution to ensuring the rights and freedoms of citizens of the Russian Federation; for a significant contribution to strengthening democracy and the constitutional system in the Russian Federation; for active social and political activities, etc.).

The resolution of the Council of Federation of the Federal Assembly of the Russian Federation dated 16.12.2009 No. 494-SF "On approval of the Regulations on the diploma of the Federation Council of the Federal Assembly of the Russian Federation" stipulates that the Honorary diploma is awarded to citizens of the Russian Federation and the organization for great contribution in development of parliamentarism, Federal legislation, legislation 
of constituent entities of the Russian Federation, local self-government strengthening, the defense and security of the Russian Federation, the implementation of social and economic policy of the Russian Federation, the development of science, culture and art, international and interparliamentary relations, active social and political activities.

Federal Executive bodies also have their own departmental awards, which can be awarded to specialists whose activities are related to local government.

These awards themselves are of great value and have great significance for the recipient. In addition, awards given to individuals may entitle them to receive the "veteran of labor" badge with an appropriate set of benefits. Measures of social support for labor veterans are defined by laws and other normative legal acts of the subjects of the Russian Federation.

4. Awards established by the state authorities of the constituent entities of the Russian Federation.

Awards found in the subjects of the Russian Federation can be grouped into the following groups: state awards of the subjects of the Russian Federation; other awards of the subjects of the Russian Federation. Types of state awards of the subjects of the Russian Federation are:

- orders and medals of the subject of the Russian Federation;

- titles of honorary citizen of a subject of the Russian Federation;

- honorary titles of the subject of the Russian Federation;

- signs of the subject of the Russian Federation;

- certificates of honor of the subject of the Russian Federation;

- state prizes (awards) of the subject of the Russian Federation.

As a rule, these awards are awarded for services to the relevant subject of the Russian Federation, a special case of which may be activities related to local government.

For example, the awarding of the insignia "For irreproachable service in the Altai Republic" is made for achieving significant results in performance, professionalism, flawless execution of duties, significant contribution to the implementation of powers of bodies of state power, bodies of local self-government, socioeconomic development of the Altai Republic, and other productive activities that have brought substantial benefits to the country. The honorary title "Honored worker of the national economy of the Republic of Kalmykia" can also be awarded to an employee of local selfgovernment bodies for personal merits. The badge of honor "for exemplary service" can be awarded to persons who fill municipal positions and municipal employees of local selfgovernment bodies of the Vologda region .

There are examples of the fact that the state award of a subject of the Russian Federation can be received by persons who have awards of local self-government bodies. In other words, the state award is indirectly related to local self-government.

The analysis of normative legal acts of the Russian Federation subjects shows that most often state awards for services to the development of local self-government are established in the republics. The most popular are honorary titles. Examples include: honored worker of local self-government (Republic of Crimea); honored worker of local selfgovernment (Republic of Mordovia, Samara region); honored worker of municipal service (Republic of North Ossetia-Alania); honored worker of state and municipal service (Udmurt Republic).

Distinctions or medals are much less common. For example, the Republic of Tatarstan 
has a medal "for merits in the development of local self-government in the Republic of Tatarstan". The Chuvash Republic has established a badge of distinction "for impeccable service in local government in the Chuvash Republic".

The reasons for receiving the abovementioned state awards are:

- outstanding achievements in the formation and development of local selfgovernment in the Republic of Tatarstan, improving the efficiency of local selfgovernment bodies, solving local issues based on the interests of the population, taking into account historical and other local traditions;

- contribution to the development of local self-government, impeccable and effective municipal service for at least 10 years;

- significant personal contribution to the formation and development of local selfgovernment in the Republic of Crimea;

- personal achievements in the development of local self-government on the territory of the Republic; in solving socioeconomic problems of municipalities; in improving the efficiency and effectiveness of professional service activities ;

- merits in the development of local self-government, implementation of measures to ensure the rule of law, rights and freedoms of citizens on the territory of municipalities of the Republic of North Ossetia-Alania, for successful and conscientious performance of their official duties, performance of tasks of special importance and complexity, who have worked in local self-government bodies for 15 years or more ;

- special merits in the field of state and municipal construction, significant contribution to the development of the provision of state and municipal services, as well as improving the activities of state bodies of the Udmurt Republic and local self-government bodies in the Udmurt Republic .
It is interesting that the above statements are made using two key terms "merit" and "contribution". It turns out that "contribution" is one of the forms of "merit". Exploring the meaning of the term "merit" A. V. Malko draws attention to the fact, as formulated in legal acts, the model of merit, seeing them as "verisonwireless": "courage", "heroism", "dresses", "high skill", "for great contribution", for "outstanding achievements", "for many years of fruitful activity", "for conscientious work" [15].

V. A. Vinokurov states that in the Russian language, merit is understood as the generally recognized utility of someone's actions, activities, as well as these actions, activities themselves, and offers to distinguish such qualitative characteristics of merit: exceptional, particularly outstanding, outstanding, special, large and simple merits. As a type of merit, you should highlight the contribution to the development of any field of activity. Like merit, a contribution to the development of something has several degrees: significant, large, weighty, special, and, in addition, there is a personal and creative contribution [1].

In all regions of the Russian Federation, activities are carried out to assess the effectiveness of local self-government bodies. The legal framework consists of decrees of the President of the Russian Federation, resolutions of the Government of the Russian Federation, acts of state authorities of the subjects of the Russian Federation, which, in particular, determine the evaluation indicators. Based on the results of the performance assessment, municipalities can receive additional awards (grants). Information about the results, which is often considered a rating of municipalities, is published for General information. These awards (grants) actually perform the same functions as awards - they are awarded in the presence of special achievements or results and are a form of recognition of merit, a measure of 
encouragement and are awarded by public Novgorod, Saratov regions);

authorities.

In the subjects of the Russian Federation, competitions for the best municipalities in General or in certain areas of activity are envisaged. The following examples occur:

- the best municipal formation of a subject of the Russian Federation (Republic of Bashkortostan, Udmurtia, Khakassia, Altai territory, Amur, Volgograd, Voronezh, Ryazan, Smolensk, Chelyabinsk regions);

- the best municipal entity for the implementation of powers in the field of development and support of small and medium-sized businesses (Leningrad region);

- the best municipality for investment attractiveness (Bryansk region);

- the best municipal formation for the maintenance and development of voluntary fire protection, water safety or in General in the area of ensuring the safety of the population (Republic of Bashkortostan, Belgorod, Omsk regions);

- the best municipal formation for effective use of agricultural economic potential of the territory and state support (Republic of Kalmykia, 2006-7);

- the best municipal formation for crime prevention (Republic of Tuva, Tomsk region);

- the best municipal formation in the field of labor protection (Udmurt Republic);

- the best municipal education in the field of education, preparation for the new school year, organization of recreation and recreation for children (Krasnodar territory, Irkutsk, Kaliningrad regions);

- the best municipal formation on the use of information and telecommunication technologies in management (Vladimir region);

- the best municipal formation on energy saving (Kurgan, Sverdlovsk region);

- the best municipal formation in the field of improvement and road activity (Nizhny
- the best municipal formation in the sphere of relations related to environmental protection (Khanty-Mansi Autonomous OkrugYugra).

An analysis of the normative acts of the above-mentioned subjects of the Russian Federation shows that the results of these competitions provide the winners with additional funds that are actually allocated to stimulate the relevant activity in the municipality.

In some regions of the Russian Federation (Altai, Khabarovsk, Krasnoyarsk territory, Volgograd, Vologda, Irkutsk, Kaluga, and Moscow regions), there is a positive experience of holding competitions for the best work of a representative body of a municipality, which are held annually by the legislative bodies of the subjects of the Russian Federation. There are examples of similar contests for precinct election commissions.

Competitions for the best municipal employees are held in almost all regions of the Russian Federation. The main awards are diplomas and awards.

Certificates of appreciation can be received not only by employees of local government bodies, but also by other persons. For the contribution to the development of local self-government of the Orenburg region, a certificate of Honor From the government of the Orenburg region, and the gratitude of the Chairman of the Legislative Assembly of the Orenburg region can be awarded .

Analysis of normative legal acts shows that almost nowhere are competitions held to identify the best control and accounting body (control body) of a municipality. Contests for elected officials, especially for deputies of representative bodies of municipalities, are rarely envisaged.

In the Republic of Sakha (Yakutia) established the badge "For merits in 
development of local self-government" in the name of Sofron Syranov (Basil Veniaminovich Syranov), which is awarded to members of representative bodies of local self-government of the Republic of Sakha (Yakutia), and achieved good practical results that have contributed to the development of local government and effective solution of issues of local importance. The badge is awarded on April 21 - the Day of local self-government in the Russian Federation. It is symbolic that Sofron Syranov in 1767 was elected a Deputy to the Catherine Commission for the development of the code of laws of Russia. In 1777, he brought to the Empress Catherine II petitions of the Sakha people to improve life, to provide the Yakuts with an opportunity to get an education.

In the subjects of the Russian Federation, such an award as "Recognition" is quite common. It is established by both state and local governments, as well as non-profit organizations. Often this award is established by public chambers. As a rule, the award is given for active activities in the field of culture, art, education, as well as socially significant or other human rights activities carried out to protect the public interest. Sometimes nominations are introduced that are directly or indirectly related to local government.

For example, the decree of the Governor of KHMAO-Ugra dated 28.09.2004 "On the Competition of socially significant projects in the sphere of social protection of the population of Khanty-Mansiysk Autonomous Okrug - Ugra" established such a category as "Best practice of territorial public self - government" - for territorial public selfgovernments that operate on the territory of the municipality of the Autonomous Okrug to create an effective social partnership between the government and the population. The winners are awarded a Statuette "award" Recognition", honorary diplomas.

\section{Awards established by local governments}

The guidelines for the development and use of official symbols of municipalities, approved by the Heraldic Council under the President of the Russian Federation on June 28, 2006, emphasize that the award signs of municipalities should not bear any resemblance (even remotely) to the state awards of the Russian Federation. The prohibition of similarity with state awards applies both to the appearance and to the names of municipal awards. It is unacceptable to use the terms "order", "badge of honor", " Honored ... "and" people's ... " for naming municipal awards, as well as other names close to the names of state awards. Award signs of municipalities must have names. For example: "Badge" Honorary citizen of the city ...", "Badge" for services to the city ...", "Badge" from the grateful ... district", "Medal" 500 years of the city ...", etc.

In practice, the above-mentioned recommendations of the heraldic Council are not always fully implemented.

Monitoring of normative legal acts of local self-government bodies shows that it is quite rare to find documents that regulate the award policy in the municipality and establish a system of municipal awards. There are examples of establishing a reward system for a municipality or a separate local government body .

As an example of a document regulating the widest range of issues related to the award policy, we can cite the decision Of the Council of deputies of the municipality "City of Novodvinsk" of the Arkhangelsk region from 09.04.2015 N 94 " on approving the Regulations on awarding municipal awards, perpetuating the memory of citizens, historical events on the territory of the municipality "City of Novodvinsk". The title of the document is very unusual, the document is aimed at regulating 
two groups of relationships - relationships related to perpetuating the memory of people or events, and the actual reward relationship.

Quite a complex award system is provided in the Krapivinsky municipal district of the Kemerovo region. Awards of the municipality, awards of local governments, as well as anniversaries are allocated. However, the regulation does not say how anniversaries are related to awards.

The anniversary dates are also mentioned in the regulations on the award system of the Ononsky district of the TRANSBaikal territory. An anniversary is a reason to get an award, but one anniversary is not enough. There should be merits that are indicated as follows: for conscientious work, high professionalism, a great contribution to the sphere of their activities (labor and social), the performance of special assignments, for assistance in conducting various types of events and (or) in connection with anniversaries, professional holidays and socially significant events in the area. The regulation sets a quota for receiving bonuses. No more than 30 citizens (families) are encouraged annually by the municipal district administration awards, including: 10 families on the anniversary of 50 years of joint life; 10 people on the anniversary of their birth (heads of budget institutions (organizations) funded from the municipal district budget are encouraged); 10 talented children.

The award system of the city of Novy Urengoy includes:

- honorary titles, which are the highest form of recognition and encouragement of citizens in the municipality.

- awards of local self-government bodies, which are divided into: awards of The city Duma of the municipality; awards of the Novy Urengoy city Administration; awards of the Novy Urengoy city Administration bodies that have the rights of a legal entity.
As already mentioned, the above examples are very rare. Usually, municipal regulations provide for both a competition to choose the best municipal entity and the best municipal employee. Such competitions are held most often by local governments of municipal districts. As a rule, the winners receive diplomas and awards, however, there may be other positive consequences for the recipient, among which the following are more common:

- recommendation for inclusion in the personnel reserve for filling the position of the municipal service in the order of official growth;

- taken into account by the attestation Commission when making a decision on the compliance of a municipal employee with the position of a municipal service (for 3 years);

- assigned an extraordinary class rank in accordance with the group of positions.

In urban districts and other municipalities, the title of honorary citizen of the city or honorary citizen of the city may be assigned. There are examples of the fact that the decision of a local government body establishes honorary titles (see, for example: Resolution of the head of the Balashikha district of the Moscow region of 17.09.2004 N 1292 "on approval of the Regulations on honorary titles of the Balashikha district by profession and the procedure for their assignment").

It is very rare for municipalities to establish their own medals. As one example, we can cite the decision of the Duma of the Kachkanarsky city district of the Sverdlovsk region from 17.05.2017 N 37 (ed. from 21.06.2017) "on the establishment of The Burdakov medal". The medal is an honorary award of the Kachkanarsky city district, established in honor of the outstanding entrepreneur, philanthropist, founder of the village of Valerianovsk, a full life member of the Ural society of natural science lovers Viktorin Yakovlevich Burdakov, in order to recognize the services of citizens to the Kachkanarsky city 
district in business, charitable and educational activities. The medal can be awarded to residents of Kachkanarsky city district, other localities of the Russian Federation, as well as foreign citizens.

\section{Awards established by public and other organizations.}

The all-Russian Congress of municipalities established a certificate of honor and a badge of honor. According to the Regulations, the certificate of Honor of the allRussian Congress of municipalities is a reward for a significant contribution to the development of local self-government, intermunicipal cooperation and training, retraining and advanced training of municipal personnel. According to the decision of the Presidium, monetary remuneration may be paid to the recipients of the certificate of Honor.

The all-Russian Council of local selfgovernment and the Union of Russian cities have their own honorary badges. In a number of subjects of the Russian Federation, municipal councils (Kursk and Orenburg) hold competitions for the best municipal formation. Such opportunities are provided by the statutes of municipal councils of the Novgorod, Ryazan, and Saratov regions)

In the Kursk region, it is the Council of municipalities that holds a competition in the following categories:" Best municipal formation"," Best head of a municipal formation, head of the municipal administration","Best representative body of a municipal formation of the Kursk region". Winners of the competition are awarded with diplomas of the Association "Council of municipalities of the Kursk region", monetary prizes and (or) valuable gifts. The winners of the competition can be nominated for participation in all-Russian competitions by the decision of the organizing Committee.

In the regions, there are competitions for the best in the profession, which are held jointly by government authorities and commercial and non-profit organizations. For example, according to the Regulations on the professional skills competition "Best lawyer of the Kama region-2019". The competition was organized by 000 "Telecomplus". The coorganizers of the competition are Perm branch of the Russian public organization "Association of lawyers of Russia", group of companies "Taxes and law", OOO "invest-Audit", NP "Union of taxpayers", the Arbitration court of the Perm region, the Seventeenth arbitration appeal court of the Perm regional court, the Office of the Ministry of justice in the Perm region, the Ministry of Finance of the Perm edge, Management of Federal tax service on the Perm edge, Management of roskomnadzora on the Perm edge, nonprofit partnership "Perm professional club of lawyers". In 2019, the competition is being implemented as part of the competition for social and cultural projects of PJSC LUKOIL in the Perm region, the Udmurt Republic and the Republic of Bashkortostan.

Competitions for the best in the profession are held in a number of municipalities by local governments.

A large number of different competitions are provided for the CBT bodies and their leaders (for example: the best CBT, the best yard, the village headman, etc.).

In November 2018, the Nenets Autonomous district launched the competition "Best CBT project 2018", which is held by the NGO" Resource center of non-profit organizations of the Nenets Autonomous district "as part of the social project" CBT of the Arctic " with the support of the presidential grants Fund.

\section{Conclusions.}

The existing regulatory legal acts and the practice of their application do not allow us to draw a conclusion about the established award policy in relation to local government bodies 
Правоприменение

2020. T. 4, № 2. С. 85-98

ISSN 2542-1514 (Print)

and the system of such awards. Monitoring of normative legal acts of local self-government bodies has shown that documents regulating the award policy of a municipality are quite rare. 


\section{REFERENCES}

1. Vinokurov V.A. State Award Law. Moscow, URSS Publ., 2014. 608 p. (In Russ.).

2. Vinokurov V.A. The system of state awards of the Russian Federation: 2018 amendments. Konstitutsionnoe i munitsipal'noe pravo = Constitutional and municipal law, 2019, no. 2, p. 18-22. (In Russ.).

3. Vinokurov V.A. Improving the legal regulation of the system of state awards of the Russian Federation. Konstitutsionnoe i munitsipal'noe pravo = Constitutional and municipal law, 2012, no. 2, p. 41-45. (In Russ.).

4. Trofimov E.V. Award engagement in the Russian Federation. Moscow, Yurist Publ., 2011. 944 p. (In Russ.).

5. Trofimov EV The award system of the Russian Federation: structural and substantive analysis. Administrativnoe pravo i protsess = Administrative law and procedure, 2012, no. 8, p. 13-19. (In Russ.).

6. Duel' V.M. State awards in Russian law: problems of theory and practice. Cand. Diss. Moscow, 2005. 181 p. (In Russ.).

7. Kapustkin A.S. The hierarchy of public awards in the Russian Federation. A view from the standpoint of law. Yurist $=$ Lawyer, 2018, no 8, p. 71-76. (In Russ.).

8. Dednev A.V. The award system of Russia as a social phenomenon: socio-philosophical analysis. Cand. Diss. Thesis. Moscow, 2009. 22 p. (In Russ.).

9. Kokurina O.Yu. Formation of award law as a complex legal institution of the Russian Federation. Gosudarstvennaya vlast' i mestnoe samoupravlenie = State power and local self-government, 2012, no. 7, p. 3-9. (In Russ.).

10. Bratanovskiy S.N., Strelnikov V.V. Administrative and legal regulation of service in bodies and institutions of the prosecutor's office of the Russian Federation. Saratov, IPR Media, 2007. 136 p. (In Russ.).

11. Serdobintseva E.V. The award system of the Russian Federation. Rossijskij yuridicheskij zhurnal = Russian Law Journal, 2010, no. 2, p. 177-181. (In Russ.).

12. Schepotiev A.V. Improvement of the award system of federal bodies of state power of the Russian Federation. Moscow, Justitsinform Publ., 2017. 80 p. (In Russ.).

13. Kapustkin A.S. Legislation on state awards. The experience of the countries of the Commonwealth of Independent States and the possibility of its application in Russia. Yuridicheskij mir = Legal World, 2010, no. 10, p. 5356. (In Russ.).

14. Kokurina O.Yu. The main functions of the interdisciplinary institute of state awards in Russian law: valueregulatory approach. Administrativnoe pravo i protsess = Administrative law and procedure, 2017, no. 12, p. 9-15. (In Russ.).

15. Mal'ko A.V. Preferential and incentive legal policy. St. Petersburg, Yuridicheskii tsentr Press, 2004.196 p. (In Russ.).

\section{INFORMATION ABOUT AUTHOR}

Ekaterina S. Shugrina - Doctor of Law, Professor;

${ }^{1}$ Leading Researcher, Center for local self government; ${ }^{2}$ Leading Researcher, Base Department of Municipal Law

${ }^{1}$ Russian Presidential Academy of National Economy and Public Administration (RANEPA)

${ }^{2}$ Ugra State University

${ }^{1}$ off. 1602, 82, Vernadskogo pr., Moscow, 119571, Russia

2 16, Chekhova ul., Khanty-Mansiysk, 628011, Russia email:eshugrina@yandex.ru

RSCI SPIN-code: 4120-8693; AuthorID: 484215

\section{BIBLIOGRAPHIC DESCRIPTION}

Shugrina E.S. Award policy: types of awards for the municipal authorities. Pravoprimenenie $=$ Law Enforcement Review, 2020, vol. 4, no. 2, pp. 85-98. DOI: 10.24147/2542-1514.2020.4(2).85-98. (In Russ.). 
